\title{
Ultra High Strength Cold Rolled Steel Sheet
}

\section{Masashi TAKahashi}

\section{1.はじめに}

自動車車体一の高張力薄鋼板の導入は, 米国に拈ける 安全自動車対策から開始されたが，その後石油資源の節 約のための然費向上が強く要請されるようになつてから 板厚低減による車体軽量化を目的に, 高張力薄鋼板の適 用が広範团な部品を対象に精力的に検討され，車体部品 に適する高張力鋼板の特性や板厚低減の可能性が明らか にされてきた1). 通常, 鋼の弾性係数は高張力化しても ほとんど変わらないため, 車体構造部材として剛性を要 求される部品には単純な高張力鋼板への置換による板厚 低減は不能であるが，強度上昇によつて板厚低減をはか れる部品も多い。特にバンパー，サイドメンバーあるい はドアガードバーのような衝突時に変形してェネルギー を吸収するのが主目的の部品への適用にはきわめて有効 である。

鋼板の強度上昇は，加工が困難となり延性も低下して くるので，成形加工して使用するには限界があるが，形 状が簡単でロール成形のような曲げを主とする万法で成 形できるため，可能な限り強度を上げた部品の例として ドアガードバーがある。このような部品を対象に引張強 さ $100 \mathrm{kgf} / \mathrm{mm}^{2}$ をこえる超高張力冷延鋼板が開発され 実用に供されている．この強度を得るための鋼の強化法 としていくつかの方法が考えられるが，自動車の車体に 適用するのであれば，成形後の熱処理による強化は焼付 硬化以外は採用し難いので所要強度にてできるだけ延性 が大きく加工に耐えること，スポット溶接が可能で必要 な強度の得られること，およびコスト的に十分安価であ ることなどが要求される。これらの目的で開発された超 高張力冷延鋼板の製造法およびその特性について以下に 紹介する.

\section{2. 製造方法と特性}

\section{$2 \cdot 1$ 回復焼鈍法}

これは米国の Youngstown 社で開発された，高張力 熱延鋼板と冷間压延後回復焼鈍の組又合わせによる方法 である2). 一般に薄鋼板の強度は泠間压延を加えること
によつて簡単に上昇させることができ，単純な低炭素鋼 を用いれば安価に高強度化できる。フェライト系の鋼の 冷間圧延率と降伏強さ増加は図 1 のよらな関係がある. しかしながら，冷間加工は大幅な伸びの劣化を来し，例 党ば炭素量約 $0.1 \%$ の低炭素鋼の焼鈍材は引張強さ約 $35 \mathrm{kgf} / \mathrm{mm}^{2}$ で 40\% 前後の 伸びがあるが，20\%の冷 間圧延にて引張強さは約 $58 \mathrm{kgf} / \mathrm{mm}^{2}$ となつても伸びは 約 $7 \%$ と大幅に 低下しさらに 30\% 以上の冷間圧延で は伸びが $3 \%$ 以下になつてしまう。な扮間圧延率が 20\%をこえると引張強さと降伏はほぼ一致する．この ように冷間加工により高強度を得る方法は加工性を著し く阻害するが，回復焼鈍によつて大きな強度低下なく延 性を改善することが可能である。

図 2 に $0.08 \% \mathrm{C}$ の低炭素鋼および $\mathrm{Ti}$ 添加鋼の冷間 加工後の焼鈍による降伏強さ，伸び拈よび軟化傾向の変 化を示すが，これらは金属組織の変化と対応しており， 焼鈍の進行にともなつて回復，部分的再結晶拉よび完全 再結晶の三つの過程に分けられる. 回復の過程は光学顕

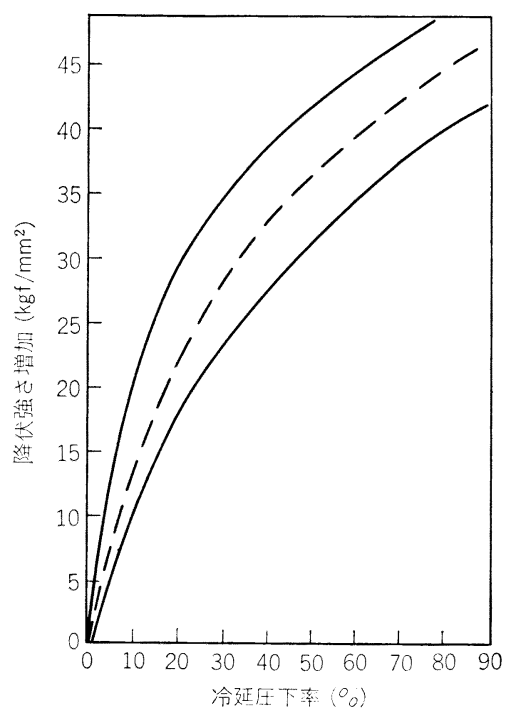

図 1 冷間压延率と降伏強さの増加 2 昭和 56 年 12 月 3 日受付 (Received Dec. 3，1981)（依頼技術資料)

* 住友金属工業(株)中央技術研究所 工博 (Central Research Laboratories, Sumitomo Metal Industries, Ltd., 1-3 Nishinagasuhondori Amagasaki 660) 


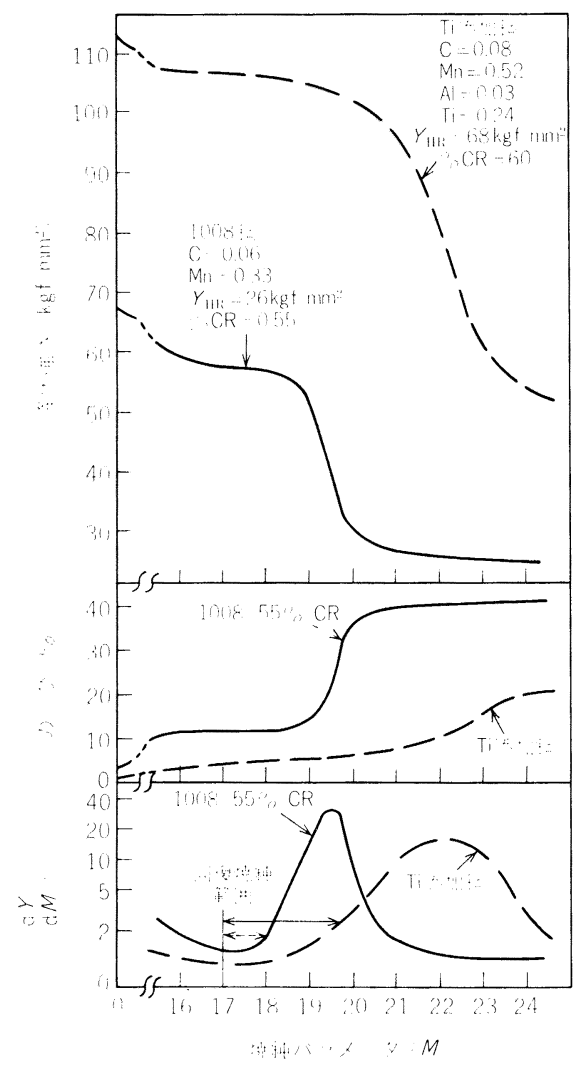

$M-T(\log t+20) \times 10^{-3}, T$ : 絶刘温度 $t:$ 時間 (s)

汹 2 焼鈍によ名降伏强さ，のび抢よび軟化傾向の 変化 ${ }^{2)}$

微鏡組織の「:ではほとんど変化はないが，電子顕微鏡観 察では転位の䏳附列や川復七几の形成が進行している.

強度の低下はわずかで，压延ままの 80～95\% 程度であ るのに対し，伸びの改率は大きくに延ままに比し $2 \sim 3$

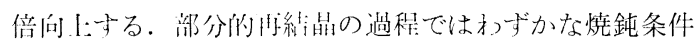
の変化で強度や伸びが大きく変わるため，安定した特性 の確保が困難で央用的でなく, 完全再絬晶の過程は加 $\mathrm{I}$ によつてト界した強度が元に厌つてしまう。

冷間圧延のた下率による強度:上物の製命は, フェライ 卜系の鋼であれば大きくは変わらない。そこで強度の高 い熱延鋼板を素材にす㞦ばそれだけ高強度の鋼板が得ら れることになる。熱延板の降伏強さを $Y_{\mathrm{HR}}$, 冷間压延ま たは加丁硬化による降代強さの洋を $\Delta Y_{\mathrm{CR}}$ とすれば， 问復燒鈍後の降伏強さ $Y_{\mathrm{REC}}$ は次のようになる。

$$
Y_{\mathrm{REC}}=K\left(Y_{\mathrm{IR}}+\Delta Y_{\mathrm{CR}}\right)
$$

ここで $K$ は 0.8〜0.95の值を取る. 降伏強さ約 $70 \mathrm{kgf} /$ $\mathrm{mm}^{2}$ の熱延鋼板を用い，約 $60 \%$ の冷間加工を行えば 上記の式から大略降伏強さ $100 \mathrm{kgf} / \mathrm{mm}^{2}$ の鋼板が得ら れることがわかる。降伏強さ $70 \mathrm{kgf} / \mathrm{mm}^{2}$ の熱延板は低 炭素鋼に Nb，V西るいは Tiなどを添加して製造され

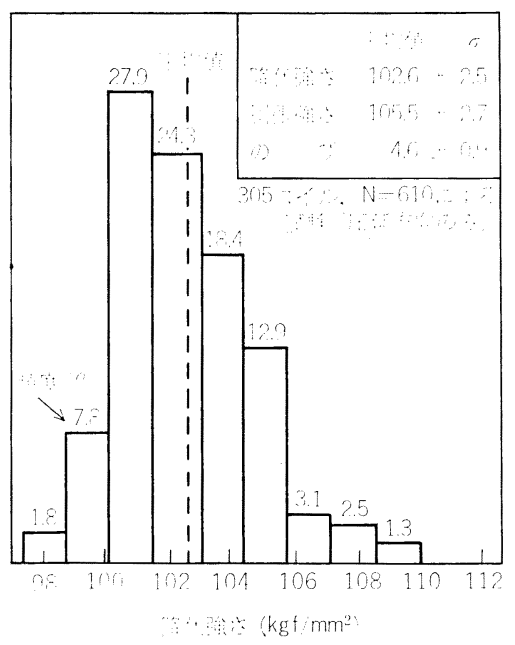

图 3 回復焼鈍法によ万超高強度泠延鋼板コイルの 降伏強分有 2 )

る.これらの元菜による強化は，炭化物や窒化物の微細 析出によつているが，これら微細析出物は冷間加工後の 焼鈍時の回復を崌らせる効果があり，回復焼鈍の範用を 払大する， $\mathrm{Ti}$ を添加した高強度熱延鋼板を用い， $60 \%$ 冷間加工:後燒鈍した例を前出の図 2 に示してあるが，回 復焼鈍の範囲が㳂く，安定した特性を得るのに有利であ る.

この回復焼鈍法は，回復が不十分であれば延性が不足 し，過剩になると急激に軟化するので，目的とする特性 のものをばらつき少なく得るには，冷間圧下率や焼鈍条 件等の製造条件の管理が重要である. Youngstowon 社 では Ti 添加鋼により降伏強さが $98 \mathrm{kgf} / \mathrm{mm}^{2}$ 級 (140 $\mathrm{ksi}$ 級）の超高強度鋼を 305 : イル作り図 3 に示すごと く平均值 $102.6 \mathrm{kgf} / \mathrm{mm}^{2}, 2 \sigma \pm 4.9 \mathrm{kgf} / \mathrm{mm}^{2}$ の結果を 得ている。 また伸びも $3 \sim 7 \%$ の範网に $95 \%$ が入つ ているとしている.

\section{$\mathbf{2} \cdot \mathbf{2}$ 水焼入法}

冷延鋼板の連続燒鈍設備にてオーステナイト域あるい はフェライトナオーステナイト域に加熱して水焼入れを 行党ば，板晢の薄い場合冷却速度を極めて大きくできる ため，此較的低成分でマルテンサイトあるいはフェライ トナマルテンサイト組織を得, 高張力鋼板を製造するこ とが可能である、合金元素を含まない低炭素鋼にて，水 焼入れを行い，低炭素マルテンサイトを得る強化法は高 強度のぶりきを得るう法として検䣄されてきだ) 5).

MCFARLAND らは水焼入れのできる連続焼鈍ラインを開 発し6)，これを伈用して自動車部品用に合金元素を含ま ない高強度の低炭素マルテンサイト鋼板を製造してい る7). 焼入れままのマルテンサイト冷延鋼板の引張特性 と炭素量の関係を図 4 に示すが8)，0.07\% C で約 110 $\mathrm{kgf} / \mathrm{mm}^{2}, 0.18 \% \mathrm{C}$ にて約 $150 \mathrm{kgf} / \mathrm{mm}^{2}$ の引張強さと 


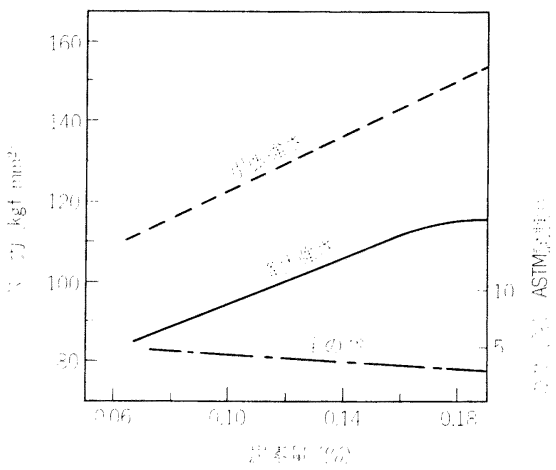

図 4 焼入れまま低炭素鋼板の機械的性質におよぼ 寸炭素量の影響8)

なる.この引張強さに対する岑䒺豐の効果として 0.04 $\sim 0.2 \% \mathrm{C}$ の範囲にて次式が提案されている3).

$\mathrm{TS}\left(\mathrm{kgf} / \mathrm{mm}^{2}\right)=837+3937 \mathrm{C}(\mathrm{wt} \%)$

このように強度は炭素量によつて大きく変わるが，伸び は約 $4 \%$ と小さくしかもあまり変化しない，低炭素、 ルテンサイトは焼入れままにてオートテンパーされるの で，勒性回復のための焼もどしは不要とされて拉り，伸 びの改善も期待されるが，さらに焼もどしを行つても強 度は大きく低下するのに対し，伸びの向上はあまり大き くない.この低炭素マルテンサイトは同じ炭素量の燒鈍 材に比較して加工硬化执よび歪み時効がはるかに大きい ため，降伏比が製造工程の影響を受けて大きく変わるの で，降伏強さよりも引張強さを基準にする方が良いよう である。焼入れままの降伏比は $0.75 \sim 0.79$ 程度である が実際の製品では $0.88 〜 0.97$ となつている ${ }^{9)}$.

冷延鋼板の水冷型連続焼鈍炉を用いて，超高張力冷延 鋼板を得る万法が中岡らによつて検討されている10)11).

炭素量 $0.11 \sim 0.14 \%$ 程度の $\mathrm{Si}-\mathrm{Mn}$ 鋼を用い，板厚 $0.6 \sim 1.2 \mathrm{~mm}$ の冷延板として高温から噴流水中に焼入 れ，200〜 $250^{\circ} \mathrm{C}$ にて焼もどし後 $0.5 \%$ の調質圧延して 特性を調査した，結果の一部を図 5 に示すが，焼入温度 を変えて引張強さ $140 \mathrm{kgf} / \mathrm{mm}^{2}$ までの超高張力鋼板を 得ている，焼入温度が高い場合マルテンサイト単相であ るが，焼入温度の低い場合はフェライトとオーステナイ トの二相共存域から焼入れされることになり，フェライ トとマルテンサイトの 2 相混合組織すなわち複合組織鋼 (Dual Phase 鋼) となる. 強度延性バランスを TS $\times$ E1 で評価すると，図に見られるように，マルテンサイ ト単相よりも複合組織になつている方が良好であるとい える，炭素量が 0.13 ～ $0.14 \%$ の鋼にて Mn 量および $\mathrm{Si}$ 量と焼入温度を変えたときの強度と伸びの 関係を図 6 に示す12). この場合いずれも焼入れ後 $250^{\circ} \mathrm{C}$ の焼も ぞしを行つている。この図から Mn 量の増加あるいは 焼入温度の上杽は強度を大幅に问上させることがわか る. 一般に Si 量の増加は Dual Phase 鋼の延性を问

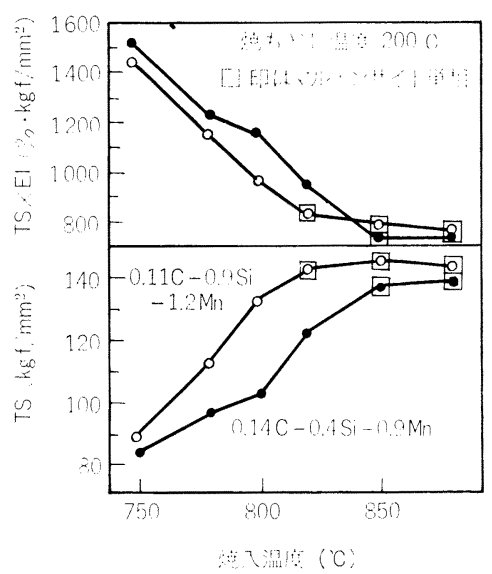

四 5 水焼入法による宫㖘力鋼板の愤入温度による 引張強さ抢よび強度－延性バランスの变化 ${ }^{10)}$

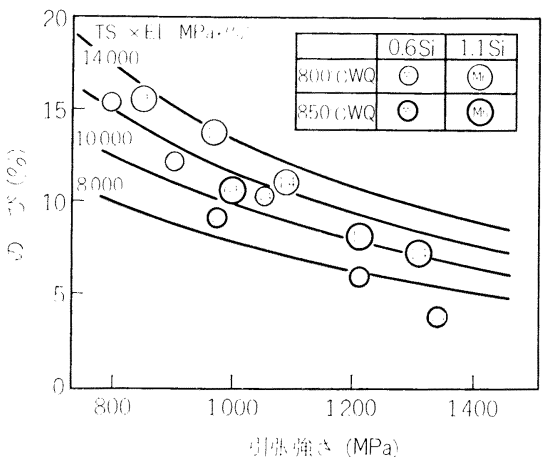

四 6 水焼入法による超简張力鋼板の強度抢よびの びに打よぼす Mn 打よび Si の影響11)

上させることは広く認められているが，この超高張力鋼 でも $\mathrm{Si}$ 量の増加は強度伸びバラン人を大きく改善して いる.

\section{$2 \cdot 3$ ガスジェット冷却法}

水焼入法のように加熱後の冷却速度を非常に大きく取 れる装置では少ない合金元素でほぼ 100\%かてれに近い マルテンサイト量を得，成分的には低ュストで超高張力 鋼板を製造できるが，ステンレスの熱处理ラインや溶融 亚鉛めつきラインを活用する埭全，あるいはガスジェッ 卜冷却による連続焼鈍ラインなど冷却速度の十分大きく ない設備にて製造するには成分や製造条件に若下のく子 らが必要となる。

溶融亜鉛めつきラインを改僬し，亚鉛ポットをバイパ スできるようにした装犆を用い $100 \mathrm{kgf} / \mathrm{mm}^{2}$ 級の超高 張力鋼板を製造した例13)14) を以下に示す。このライン は板厚 $3.2 \mathrm{~mm}$ のものまで処理でき, 最滆加熱温度が $1000^{\circ} \mathrm{C}$, 冷却速度は $1.2 \mathrm{~mm}$ 厚の板で約 $20^{\circ} \mathrm{C} / \mathrm{s}$ であ る.このラインにより超高張力鋼板を得るための製造条 作を $1.2 \mathrm{~mm}$ 厚の冷近鋼板により, 成分抢よび加熱温度 


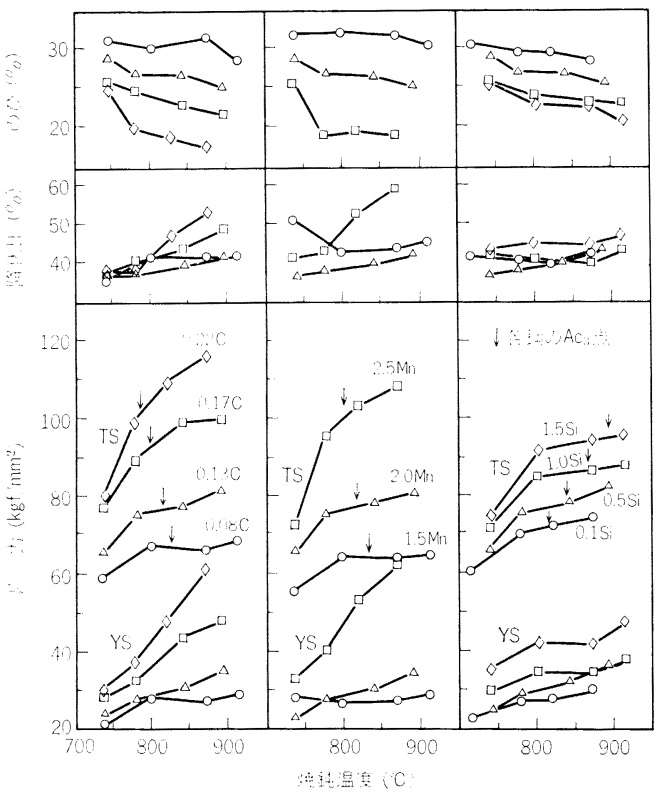

四 7 ガスジェット冷却法による張力銅板の機械 的性啠におょ活年 C, Mn, Si の影留14) (ベース成 分: $0.13 \mathrm{C}-0.5 \mathrm{Si}-2.0 \mathrm{Mn}-0.04 \mathrm{Al}$ )

变变て検剧した。基本成分を $0.13 \mathrm{C}-0.5 \mathrm{Si}-2.0 \mathrm{Mn}$ と L，C，Si，Mn 早および加熱温度を变えた場合の強度 および伸びの変化を図 7 に示す.引張強さ $100 \mathrm{kgf} / \mathrm{mm}^{2}$ 以上の超问張力鋼板を得るには $\mathrm{C}$ 量を $0.17 \%$ 以上ある いは Mn 箸を $2.5 \%$ 以上とし，加熱温度を $800^{\circ} \mathrm{C}$ 以 上と高くする必䧇があり，水焼入法に比較して合金成分 が多く必要である。この場含，加熱温度がフェライト十 オーステナイト域であればフェライト+マルテンサイト 組織になるが，加熱渭度がオー火テナイト域になるとべ

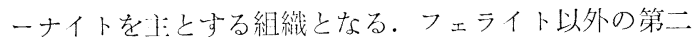

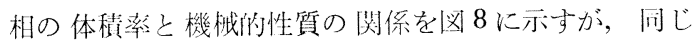
$100 \mathrm{kgf} / \mathrm{mm}^{2}$ 級でもフェライト+マルテンサイト組織の 場合よりもべーナイトに:体の縕織の才が降伏点が高く伸 びがすぐれているよらである。またこの製造法で，曲げ

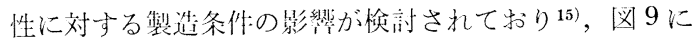
示すよらに $\mathrm{Ac}_{3}$ 䈍以上の焼鈍が良好である。これは才 ーステナイト域への加熱によるバンド組織の消失による 之考えられる.

二相共存域に加熱後，邀当な冷却速度で急冷しフェラ イトナマルテンサイト組織にする Dual Phase 鋼にお いてその強度はマルテンサイトの体積率に比例して上早 するとされて抢り ${ }^{16)}, 100 \mathrm{kgf} / \mathrm{mm}^{2}$ 級の鋼を得るには約 60\%のマルテンサイト相が必要と推定される. 此較的 冷却速度の遅い没储を用いて高强度のDual Phase 鋼を 得るには，上述のようにC 早を增与か，合金元紊を添加 寸る方法が考えられる。 C些の增加は, 二相共存域に加 熱したときのオーステナイト蝟を增し冷却後のマルテン

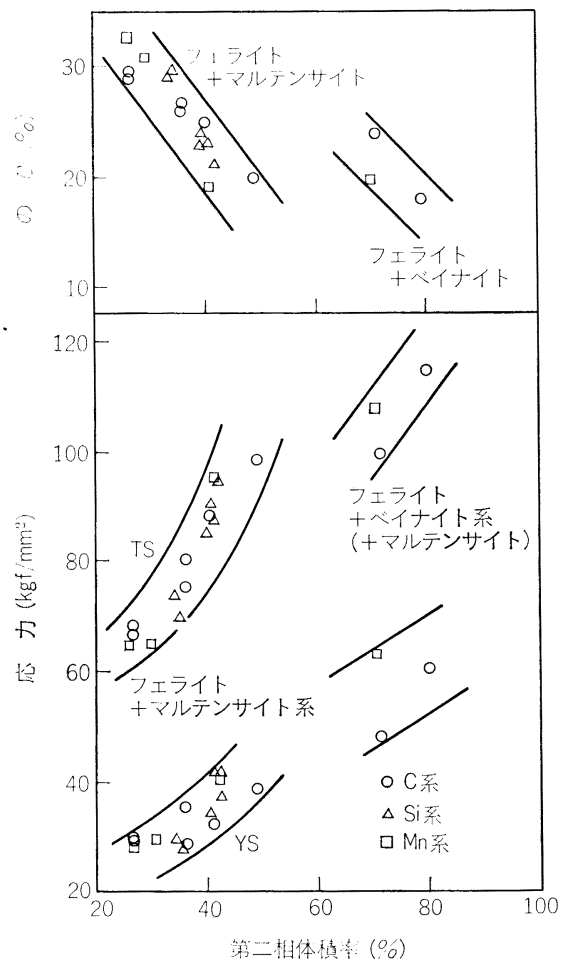

図 8 ガスジェット玲却法による滈張力鋼板の第二 相体積摔と機械的性質の関係 ${ }^{14)}$

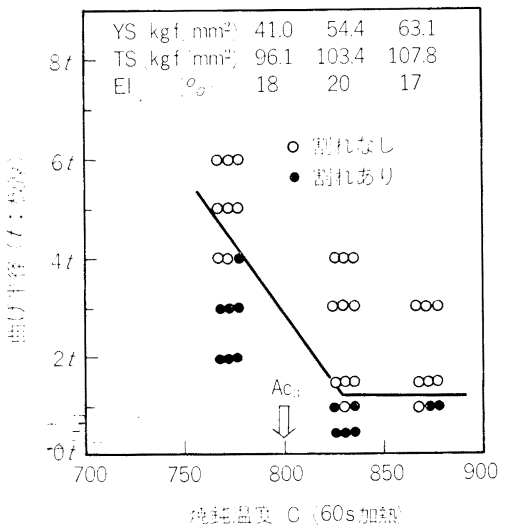

汹 9 ガスジェット冷却法による超宫張力鋼板 (0.14C-0.5Si-2.5Mn-0.0Al) の曲げ性におよ

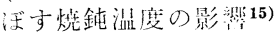

サイト量を多くするものであるが，溶接性を劣化させる ので限界がある．合金元素の添加はオーステナイトの焼 入性を问上させ冷却後のマルテンサイト量の増加をはか るもので Mnの他 $\mathrm{Cr}, \mathrm{Mo}, \mathrm{V}$ 等が利用されるがコス ト高となる。

次に，ガスジェット冷却法による冷延鋼板の連続焼鈍 ラインを利用した例として，権藤らは未細結晶フェラ 
イと島状マルテンサイトとの複合組織による $100 \mathrm{kgf} /$ $\mathrm{mm}^{2}$ 級冷延鋼板の㹈造法を報售している17)。これは $0.092 \mathrm{C}-0.25 \mathrm{Si}-2.1 \mathrm{Mn}$ の低炭素鋼に Ti 加したアルミキルド鋼を, 冷间伯延後二相其存域の比較 的低温側に加熱し $2 \sim 5^{\circ} \mathrm{C} / \mathrm{s}$ の速度で冷却与る。烧鈍の 加熱温度と強度および伸びの栭係は四 10 に示ずごとく で，焼鈍温度が $\mathrm{Ac}_{1}$ 以上になると生じたオーステナイ トが連続焼鈍ラインの急冷によりマルテンサイト化する

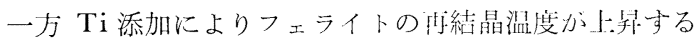
ため, 再結晶粒が認められるのは $800^{\circ} \mathrm{C}$ 以上となるの

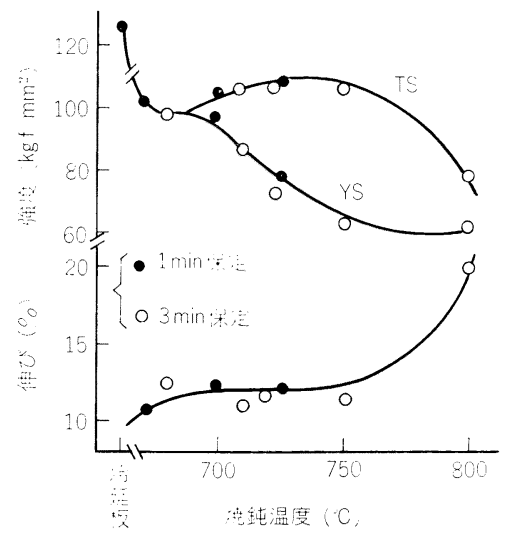

図 10 ガスジェット型連続焼鈍ラインによる超问张 力鋼板の機械的性質に戈上ぼす焼鈍温度の影聯 17
で 730〜 750 ${ }^{\circ} \mathrm{C}$ の焼鈍温度を邀べば，未再絬晶フェライ トとマルテンサイトの複令組織が得られる。このように 一種の回復焼鈍であるため收適滥度範明はせまいが連続 焼鈍の利点として均一な篡処理が可能で，仰びが $10 \%$ をこ光降伏比 $0.75 \sim 0.85$ の加工性のすぐれた $100 \mathrm{kgf} /$ $\mathrm{mm}^{2}$ 級の鋼板が得られるとしている。

\section{4 各製造法による製品特性}

上記の各製造法により, 包際の工場没供にて製造され た製品の特性について報告されたデータをまとめると表 1のよらになる。回復焼鈍は降伏強さが离く，伸びは大 きくないが，特別の設備なしに製造できる利点がある。 水焼入れによるマルテンサイト鋼は成分的に最も安価で あるが，伸びがやや低くなる傾问があり，Dual Phase 鋼は降伏点が低く良好な伸びを示す。ガ火ジェット冷却 は水焼入れ法に比べ Mn や Cr などを多く添加する必 装がある. このように $100 \mathrm{kgf} / \mathrm{mm}^{2}$ 級の超高張力冷延 鋼板に対し，種々の製造法が提案され，異なつた特性の 製品が製造されているが，適用する部品に荘求される加 工性，活用できる製造設備，および製造コ火トの点から 製造法が選定されているものと思われる。

\section{3. 実部品への適用}

超高張力冷延鋼板の伯動車部品への適用例に初的に も述べたごとくドアガードバーがあり, 超高張力冷延鋼 板の特性もこれができることを一つの日標としているた め, 以下これを対象に材料特性を考えてみる. ドアガー

裴 1 超㫦張力冷延鋼板の製造例

\begin{tabular}{|c|c|c|c|c|c|c|c|c|c|c|c|c|c|c|c|}
\hline \multirow[b]{2}{*}{ 製造設備 } & \multirow[b]{2}{*}{ 処理条件 } & 化 & & 成 & 分 & $(\%)$ & \multirow[b]{2}{*}{$\begin{array}{c}\text { 板厚 } \\
(\mathrm{m} \mathrm{m})\end{array}$} & \multirow[b]{2}{*}{ 方向 } & \multirow{2}{*}{$\begin{array}{c}\mathrm{Y} \mathrm{S}^{\text {傤 }} \\
\left(\mathrm{kgf} / \mathrm{mm}^{2}\right)\end{array}$} & \multirow{2}{*}{$\underset{\left(\mathrm{kgf} / \mathrm{mm}^{2}\right)}{\mathrm{T}}$} & \multirow{2}{*}{$\begin{array}{l}\text { 列 } \\
\mathrm{E} 1^{*} \\
(\%)\end{array}$} & \multirow[b]{2}{*}{ Y R } & \multirow{3}{*}{$\begin{array}{l}\| 11 b f^{2} \\
(t)\end{array}$} & \multirow{2}{*}{ 組 } & \multirow{2}{*}{ 文献 } \\
\hline & & C & $\mathrm{Si}$ & $\mathrm{Mn}$ & $\mathrm{Al}$ & $\mathrm{Ti}$ & & & & & & & & & \\
\hline 箱焼鈍鿉i & $\begin{array}{l}\text { 回復温度 } \\
\text { 域嵝鈍 }\end{array}$ & 0.07 & - & 0.84 & 0.04 & 0.27 & 1.1 & $\mathrm{~L}$ & $\begin{array}{l}105.1 \\
116.9\end{array}$ & $\begin{array}{l}108.6 \\
120.5\end{array}$ & $\begin{array}{l}7 \\
4\end{array}$ & $\begin{array}{l}0.97 \\
0.97\end{array}$ & & 回復組織 & 2 \\
\hline \multirow{4}{*}{$\begin{array}{c}\text { 連続焼錦 } \\
+\begin{array}{c}+ \\
\text { 水狫入装置 }\end{array}\end{array}$} & \multirow[t]{4}{*}{$\begin{array}{l}\mathrm{Ac}_{3} \text { 以上加熱 } \\
\text { 水绫入れ }\end{array}$} & $\begin{array}{l}0.06 \\
\sim 0.09\end{array}$ & $9-$ & $\begin{array}{l}0.30 \\
\sim 0.60 \\
\sim\end{array}$ & - & - & 0.9 & $\begin{array}{l}\mathrm{L} \\
\mathrm{T}\end{array}$ & $\begin{array}{l}86.8 \\
92.7\end{array}$ & $\begin{array}{l}113.3 \\
120.1\end{array}$ & $\begin{array}{l}3.7 \\
3.6\end{array}$ & $\begin{array}{l}0.77 \\
0.77\end{array}$ & $\begin{array}{l}4 \\
7\end{array}$ & \multirow[t]{4}{*}{$\begin{array}{l}\text { マルテンサイ } \\
\text { ト }\end{array}$} & 7 \\
\hline & & $\begin{array}{l}0.10 \\
\sim 0.12\end{array}$ & - & $\begin{array}{l}0.30 \\
\sim 0.60\end{array}$ & - & - & & $\begin{array}{l}\mathrm{L} \\
\mathrm{T}\end{array}$ & $\begin{array}{l}97.2 \\
98.1\end{array}$ & $\begin{array}{l}127.2 \\
128.6\end{array}$ & $\begin{array}{l}4.0 \\
3.1\end{array}$ & $\begin{array}{l}0.76 \\
0.76\end{array}$ & & & \\
\hline & & $\begin{array}{l}0.15 \\
\sim 0.17\end{array}$ & - & $\begin{array}{l}0.30 \\
\sim 0.60\end{array}$ & - & - & & $\mathrm{L}$ & 112.7 & 144.3 & 3.9 & 0.78 & & & \\
\hline & & $\begin{array}{l}0.18 \\
\sim 0.20\end{array}$ & - & $\begin{array}{l}0.30 \\
\sim 0.60\end{array}$ & - & - & & $\begin{array}{l}\mathrm{L} \\
\mathrm{T}\end{array}$ & $\begin{array}{l}116.1 \\
109.6\end{array}$ & $\begin{array}{l}154.3 \\
158.9 \\
\end{array}$ & $\begin{array}{l}3.8 \\
3.3 \\
\end{array}$ & $\begin{array}{l}0.75 \\
0.69\end{array}$ & & & \\
\hline \multirow{5}{*}{$\begin{array}{l}\text { 水焼入型連続焼 } \\
\text { 鈍ライン }\end{array}$} & \multirow{5}{*}{$\begin{array}{l}\mathrm{Ac}_{3} \sim \mathrm{Ac}_{3} \text { 間ま } \\
\text { たは } \mathrm{Ac}_{3} \text { 以上 } \\
\text { 妿熱水煤入れ } \\
200^{\circ} \mathrm{C} \text { 焼もどし }\end{array}$} & 0.11 & - & 0.5 & - & - & 0.6 & & & 102.0 & 5.1 & & 5.0 & \multirow{5}{*}{$\begin{array}{l}\text { フェライト+ } \\
\text { マルテンサイ } \\
\text { ト } \\
\text { またはマルテ } \\
\text { ンサイト }\end{array}$} & 9 \\
\hline & & 0.14 & 0.4 & 0.9 & - & - & 0.8 & & & 103.1 & 11.2 & & 5.0 & & \\
\hline & & 0.13 & & 0.5 & - & - & 0.9 & & & 132.2 & 3.8 & & 5.5 & & \\
\hline & & 0.14 & 1.12 & 0.44 & - & - & & & & 103.5 & 10.9 & & 1.0 & & 10 \\
\hline & & 0.14 & 0.31 & 1.32 & - & - & & & & 140.4 & 5.6 & & 2.0 & & \\
\hline $\begin{array}{l}\text { 溶融亜鉛めつき } \\
\text { 放造ライン }\end{array}$ & $\begin{array}{l}\mathrm{Ac}_{3} \text { 以上加熱ガ } \\
\text { スジット却 }\end{array}$ & 1.3 & 0.50 & 2.6 & 0.045 & - & 1.2 & $\begin{array}{l}\mathrm{L} \\
\mathrm{T}\end{array}$ & $\begin{array}{l}75.4 \\
75.0\end{array}$ & $\begin{array}{l}105.3 \\
106.2\end{array}$ & $\begin{array}{l}16.4 \\
16.2\end{array}$ & $\begin{array}{l}0.72 \\
0.71\end{array}$ & $\begin{array}{l}1.5 \\
2.0\end{array}$ & $\begin{array}{l}\text { ベーナイト+ } \\
\text { フェライト }\end{array}$ & 13 \\
\hline \multirow{2}{*}{$\begin{array}{l}\text { ガスジェット冷 } \\
\text { 却 } \\
\text { 連続焼鈍ライン }\end{array}$} & \multirow{2}{*}{$\begin{array}{l}\mathrm{Ac}_{1} \sim \mathrm{Ac}_{3} \text { 間加 } \\
\text { 熱, ガスジェッ } \\
\text { ト冷却 }\end{array}$} & \multirow[t]{2}{*}{0.092} & 0.25 & 2.1 & 0.022 & 0.082 & $\begin{array}{r}1.2 \\
-\end{array}$ & $\begin{array}{l}\mathrm{L} \\
\mathrm{T}\end{array}$ & $\begin{array}{l}77.0 \\
86.8\end{array}$ & $\begin{array}{l}100.8 \\
103.2\end{array}$ & $\begin{array}{l}12 \\
11\end{array}$ & $\begin{array}{l}0.76 \\
0.84\end{array}$ & 2.0 & \multirow{2}{*}{$\begin{array}{l}\text { 回復組織 } \\
+ \pm \\
\text { マルテンサイ } \\
\text { ト }\end{array}$} & 16 \\
\hline & & & & & & & 1.0 & $\begin{array}{l}\mathrm{L} \\
\mathrm{T}\end{array}$ & $\begin{array}{l}78.6 \\
94.7\end{array}$ & $\begin{array}{l}105.6 \\
113.1\end{array}$ & $\begin{array}{r}12 \\
9\end{array}$ & $\begin{array}{l}0.74 \\
0.83\end{array}$ & 2.0 & & \\
\hline
\end{tabular}

* 交献 2) および 7) の場合A S TM堿験片 
ドバーは図1118)に示与ようにドア内部に収められ，白 動車の側面からの衝突に対しドアの変形を小さくしょら とするもので，米间ではこの側向衝突安全性が法規化さ れ，ドアの変形蟔度について MVSS No 214 の规格が ある.したがつて，このドアガードバーは常時灾力が加 わることはなく，衝突時に多形してェネルギー吸収の役 目を果たせばよいのでできるだけ軽市でかることが好ま しい.

ドアガードバーの形状は波形の断而で，ロール成形ま たは曲げ加工を主体に成形するため加工性はそれ和ど娶 求されない。しかし同じ引張強さで㔚れば，降伏強さが 低く，仰びの大きいうが成形上好ましく，Dual Phase 鋼が有利である。一方衝突時の変形によるエネルギー吸 収に対し，降伏咨の影響が検討されている。これはバン パーをモデルに成形品を後出の戍 13 内に示すような三 点曲げを行い，折曲げの压壊強度に対する材料特性が調 查されたものである19)。その結果によれば，压壊の最大 荷重 $P_{\max }$ は鋼板のひ-゙み $3 \%$ のときのフローストレ

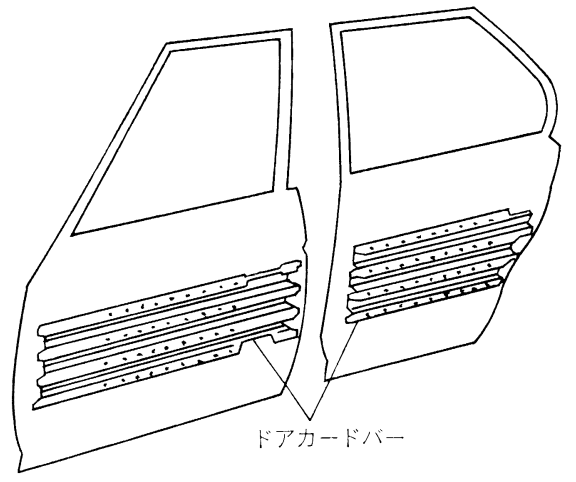

図 11 ドアガードバーのドアへの取り付け18)
大 $\sigma_{3}$ と非常に良い相関を示すが， $\sigma_{3}$ を引張強さ TS と 降伏強さYS の斗均优で技さかえても良く，板厚を $t$ と ナれい゙，

$$
\begin{aligned}
& P_{\max }=a[(\mathrm{TS}+\mathrm{YS}) / 2]^{0.8} \cdot t^{2} \\
& \quad(a \text { は係数 })
\end{aligned}
$$

で衣さ机ることを示している。これから低降伏比のDual Phase 鋼を使用しても压塯強度は十分期待できるといえ る.

部品への組み立てあるいは車体への取り付けはスポッ ト溶接が主となる。鋼板の製造条件により溶接部強度と 母材強度の関係が大きく翼なつてくると推測されるが， 詳細な報告は少なく, 成分や強度による溶接条件の変更 は市つても在来の設備で十分対応できるようである。こ

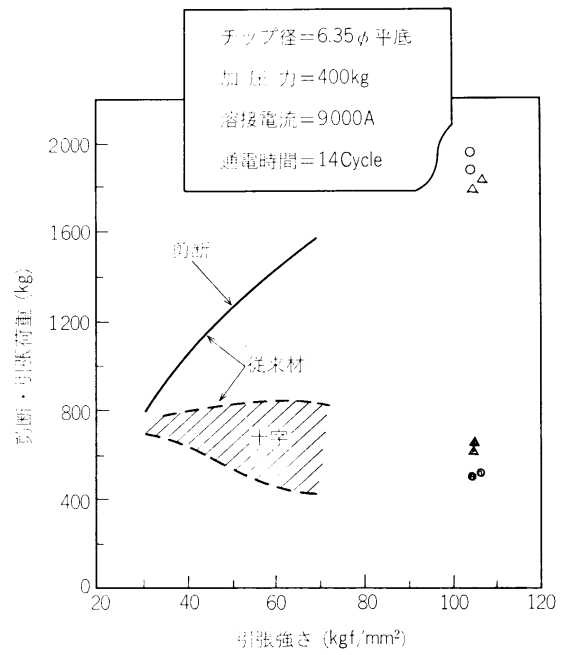

図 12 超问张力鋼のスポット溶接強さ11)
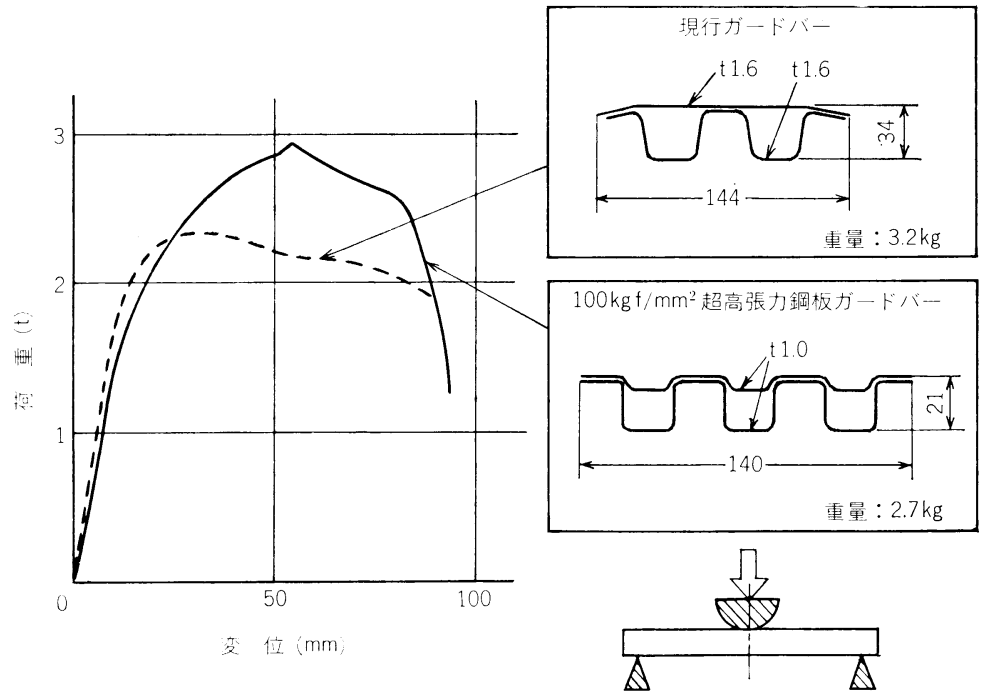

図 13 ドアガードバーの単体曲げ試験 21) 

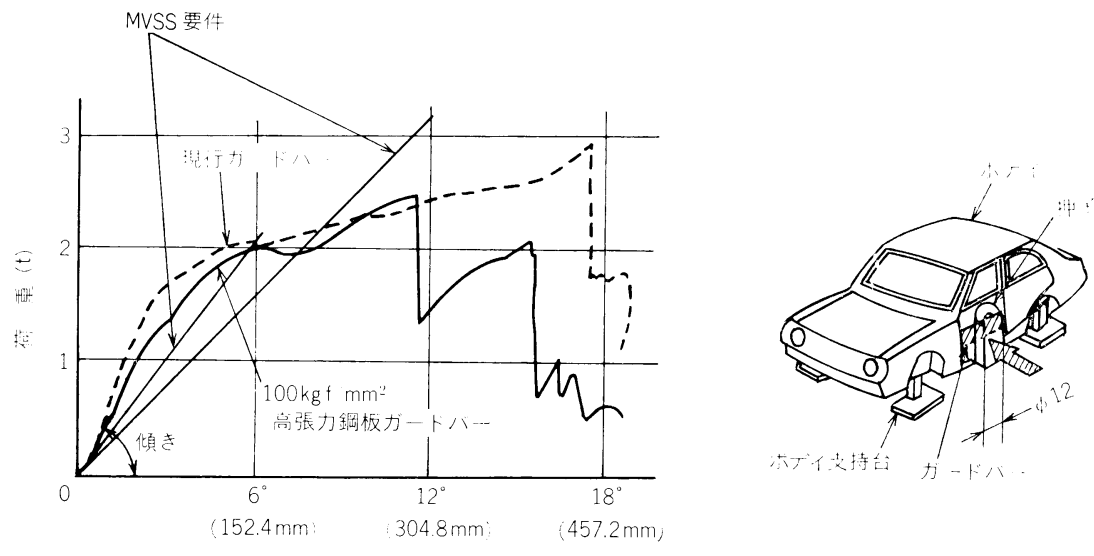

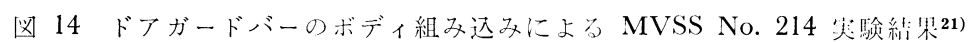

れは溶接部がドアガードバーの变形強度に直接影㿥しな い部位になるからであろら。ガスジェット冷却法による $100 \mathrm{kgf} / \mathrm{mm}^{2}$ 級鋼にて母材引張強さと剪断求よび十字引 張強さの関係を調查した例を汹 12 に示すが14)，剪断强 さは母材引張強さとともに上㫘し，十字引張強さはあま り変化しないといら従来の高強度鋼板で認められる倾问 の延長上にあることがわかる.

この超高張力鋼をドアガードバーに適用するに当た り，高強度を生かした断面形状の検㿟が種々行われてい る20)21)，素材強度が高い分単純に板厚を低減したのでは 座屈現象が顕著に発生し，エネルギー吸收特性が低下与 るので，断面形状の設計要件を検討してこれに対処した 例を図 13 および図 14 に示す21). $60 \mathrm{kgf} / \mathrm{mm}^{2}$ 紋の鋼 板を使用した従来のドアガードバーに比し，㸝又が 34 $\mathrm{mm}$ から $21 \mathrm{~mm}$ に薄くなり，使用鋼板㕌さが $1.6 \mathrm{~mm}$ から $1.0 \mathrm{~mm}$ に減少し $15 \%$ 軽童化されたにもかかわ らず，三点曲げの場合より高い圧填荷重を得，ドアに組 夕込んだ結果でも従来のものよりも若千荷重は低くなる が，MVSS 条件を十分満足するものを得ている.

\section{4.おわりに}

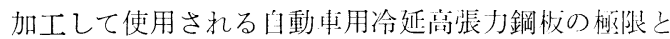
考えられる $100 \mathrm{kgf} / \mathrm{mm}^{2}$ 級超高张力冷延鋼忺に対して いくつかの製造法が提案され，製品が作られている。乙 の製造法は製品に要求される特性および加区性と活用で きる製造設備あるいは製造コストの点から選定されてき た．現状では形状が簡単なドアガードバー等にしか实部 品としては採用されていないが，衝突時の衝撃力緩和の ために 60〜 $100 \mathrm{kgf} / \mathrm{mm}^{2}$ の鋼板が用いられる部材で通 常高い静荷重や変動荷重を受忷ないものは超高張力鋼板 の使用によりさらに軽量化できる可能吽がある。これを 阻をものは加工の困難さと材料の延性の低下であるが， 加工技術の進歩および製造技術の改善により，これら超
高張力鋼板の使用显は增加して行くと考兄られる.

\section{交献}

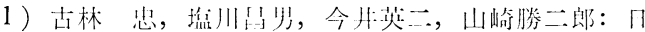
産技報，(1979) 14，p. 31

2) $P . B$. Lake and $J . J$. Grenawalt: S $\Lambda \mathrm{E}$ paper 770163 (1977)

3 ) W. H. McFarland: Trans. AIME, 233 (1965), p. 2028

4 ) $K . J$. Albutt and S. Garber: JISI, 204 (1966), p. 278

5 ) J. M. WAllbridge and $J . G$. PArR: JISI, 205 (1967), p. 750

6) W. H. MaFarland: U. S. Patent No. 3,378, $360(1968)$

7 ) W. H. MaFarland and $H . L$. Taylor: SAE paper 690263 (1969)

8 ) P. R. Mould: SAE paper 740953

9 ) T. E. Fine and S. DINDA: SAE paper $750222(1975)$

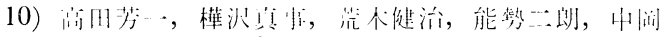
一秀：鉄之錩，63 (1977)，\$317

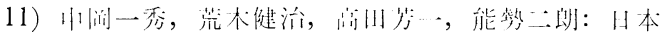
銅管技報，(1977) 75，p. 253

12) $K$. Nakaoka, $Y$. Hosoya, $M$. Ohmura, and A. Nishimoto: Structure and Properties of Dual-Phase Steels, ed. by $R$. $A$. Kot and $J . W$. Morris (1979), p. 330 [AIME]

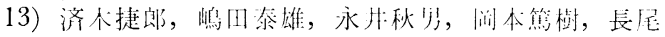
典㛝：铁之铜，66 (1980)，S 957

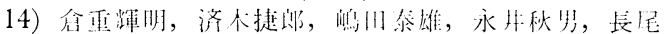

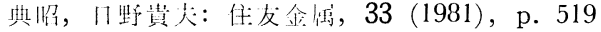

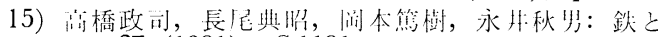
龬, 67 (1981), S 1181

16) R. G. Davis: Met. Trans., 9A (1978), p. 671

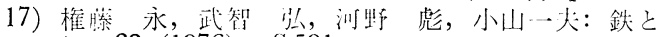
鐥, 62 (1976), S591

18) S. Dinda, D. K. Kelley, and A. S. Kasper: SAE paper 780139 (1978)

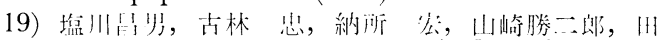

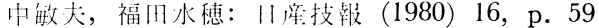

20) T. E. FinE and S. DINDA: SAE paper 750222

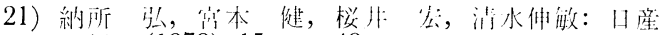
技報，(1979) 15, p. 49 